\title{
Influence of Youth Self-Help Group Members Skills on Group Performance in Aldai Constituency, Nandi County, Kenya.
}

\author{
Peter Kiprotich, Dr. Jane Wangaruro, Dr. Gladys Nyachieo \\ Scholar of MA (Honors), department of sociology Kenyatta University (Kenya) \\ Lecturer Kenyatta University \\ Lecturer Kenyatta University
}

\begin{abstract}
The study focused on the effects of acquired skills through education and training on the performance of youth Self-Help Groups (SHG). A multi stage sampling was used to get a sample of 136 youth SHG members who participated in the study from the 56 youth groups that were sampled out. Other key informants were also interviewed. Structured questionnaires and interviews were used in collecting data which was analysed using appropriate descriptive techniques. The study results revealed that there were no positive relationship between the the level of education and the performance of youth SHGs. It was found that inadequate skills, ignorance and limited finances were some of the challenges affecting youth SHGs. The study recommends a follow up and involvement of local leaders and experts on the implementation of youth programmes.
\end{abstract}

Keywords: Self Help Group, Youth, Skills, Education, Performance and livelihoods.

\subsection{Introduction}

Self-Help Group (SHG) is formed when people with the same socio-economic status in the community come together in order to pool resources for mutual benefits in livelihood improvement (Kenya Self-Help Association Bill, 2015). The aim of SHGs is to facilitate access of credit, economic development, sharing of business ideas and mutual prosperity among the group members (Moraa, Mwangi, \& Bor, 2014). The rising youth population in the developing countries have led the government and private organisations to mobilise youths to form youth SHGs in order to access economic resources to improve on their livelihoods. The 2015 UN population statistics indicates there are 226 million youths of ages between 15-24 years and the numbers might be even higher for the youths between the ages of 18-34 years. The growing population of youths therefore are of concern to every government in Africa and other stakeholders. Majority of the youths in Africa experience challenges such as underemployment, unemployment, poor system of education, lack of skills and limited access to capital (Africa Union, 2011) these challenges may negatively affect the creativity and innovativeness of the youths in the labour market. The rising population has led to scarcity of job opportunities in the formal sector and therefore informal sector remains the main source of employment to majority of the youths (International Labour Organisation, [ILO] 2012). In Kenya, the government has been committed to reform and expand youth polytechnics as a way of promoting skill development to enhance self-reliance among the youths (Balwanaz, 2012). In 2006, Kenya National Youth Policy was formed to provide a policy framework for livelihood improvement for the youths. Since then, the government has been establishing welfare programmes for the youths such as Youth Enterprise Development Funds, Kazi kwa Vijana and Uwezo fund. Youth SHGs were therefore established to allow youths to access financial resources from such welfare programmes.

\section{Statement of the Problem}

The high unemployment rate in Kenya has made the government to establish welfare programmes for the youths. Youth self-help groups were identified by the government as the convenient way of reaching out to most of the youths. Furthermore, the government has made commitment of establishing youth polytechnics and tertiary institutions in the country that have led to mass graduates from such institutions. Despite the 
high number of youths graduating from these academic institutions, creativity and innovation in the labour market is still low and this is reflected from the high number of youths who are economically dependent irrespective of their education level.

\subsection{Literature Review}

Unemployment rate in Africa is influenced by the impact of skill utilization especially in the informal sector such as youth self-help groups. The ideology of using self-help groups in developing countries as an economic empowerment agent was based on the self-help group approach that was established in India in the early 1980s (Fernandez, 2007). Participation of youths in the groups creates ownership, management and control concerning goals and outcome (Brody et al., 2013). The Kenyan government has been therefore encouraging the youths to form groups to facilitate access of economic resources from the government and other stakeholders.

Skill utilization in self-help groups helps improve on the productivity. In Nigeria extension approach which involves training of rural people on improved techniques of farming, healthcare and even on how to read and write was adopted to improve on the livelihoods of the rural poor (Akpomuvie, 2010).This proves that skill utilization is a necessity in the informal sector that should be adopted in all fields of economic production. The report by Friendrich-Ebert-Stiftung Foundation and Institute of Economic Affairs indicates that institution of learning such as Technical, Industrial, Vocational and Education Training (TIVET) are important in offering practical skills to the youths. Skills therefore are required for the creation of jobs although the notion has been criticized on the basis that skill development requires an enabling environment and it does not exist in a vacuum (Balwanz, 2012;King, 2012). Participation of all stakeholders such as government, private sector and Non-governmental organisations creates an enabling environment for skill development and hence creation of more jobs in the informal sector.

The employment rate in Kenya is $67 \%$, this means that the youths who enter the labour market annually without skills are over one million (Kaane, 2014). Youth self-help groups in Kenya are not an exception in the informal sector and therefore they might be experiencing the challenge. The Kenyan government introduced the Kenya National Youth policy of 2006 to provide a policy framework on intervention of youth challenges, its more than 10 years since the programme was introduced yet youth still face challenges such as access to finances, unemployment and lack of skills (Africa Union, 2011). The more investment done in the education system should be clearly reflected in the labour market based on creativeness and utilization of relevant skills to improve on the productivity.

\section{Human Capital Theory}

Human capital theory was adopted in the study in understanding human beings as an asset in the community. Adam Smith first used the theory in 1776 where he asserts that acquisition of education is a capital investment to a person, which is a fortune to an individual and likewise to the society (Diebolt \& Haupert, 2016). Based on the theory, skills in the informal sector are fundamental in job creation and livelihood improvement in the community. Skill utilization in the labour market will therefore lead to more revenue to the country thus becoming beneficial to both the community and society.

\section{Figure 1: conceptual model}

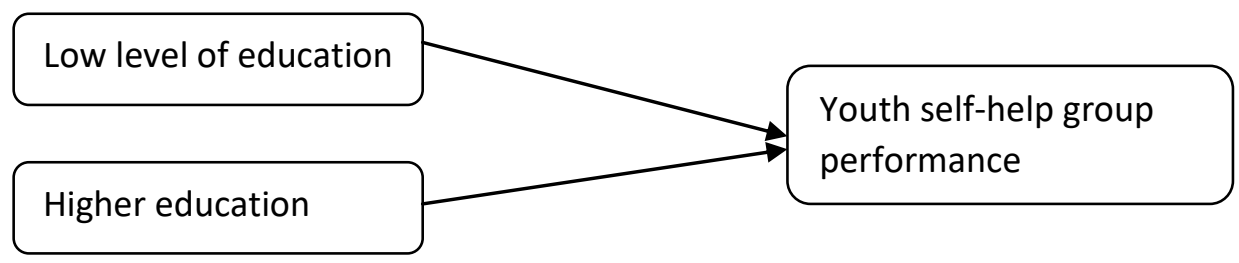

Low level of education entailed primary and secondary school education. According to (Rolleston, 2014) primary and secondary education help in development of basic cognitive skills which can be transformed to more complex skills such as problem solving and ability to use new technologies. A strong foundation of cognitive skills enables young people to be resilient with group challenges and adopt better technologies to improve on their output. Higher education such as youth polytechnics enhances specialization of skills that help creates employment (Balwanaz, 2012). Skill specialization contributes to more output in the labour market that would in turn improve on livelihoods of the young people. 


\subsection{Methodology}

Aldai constituency is in Nandi County, Kenya. Nandi south sub-county is made up of the entire Aldai constituency. The constituency as per the 2009 Kenyan population census has a population of 146,256 people. The constituency is made up of six wards that include: Kobujoi, Kemeloi, Kabwareng', Terik, Kaptumo/Kaboi and Koyo/Ndurio. The total numbers of groups in Nandi south are 256 out of which 56 comprises youth groups, this is according to the department of youth, gender and social services of Nandi South. Multi stage sampling was adopted with the use of purposive sampling in selecting youth SHGs from different wards and simple random sampling in selecting 136 youth group respondents from 56 youth groups. A sample size of $10 \%$ to $30 \%$ of a study population is ideal for a study (Mugenda \& Mugenda, 2003) therefore the study used $20 \%$ of the study population. Structured questionnaires and structured openended interviews were used to collect data.

\subsection{Data Analysis and Results}

The demographic characteristics of the respondents were based on gender, age, marital status and level of education. The gender distribution of the respondents was $63.2 \%$ male and $36.8 \%$ female. Majority of the respondents $(56.6 \%)$ were between the age of 26 to 35 as opposed to those between the age of 18 to 25 years. The study also revealed that most of the youths (52.9\%) participating in groups were single although the gap with the married was minimal $(42.6 \%)$. The level of education, which is important in the study in determining skill development were found that majority $(41.2 \%)$ had secondary education also most of them had college/polytechnics education (30.9\%). The high number of youths with secondary and post-secondary education as indicated in the study should have a positive impact to the labour market. According to (Jayaram \& Engmann, 2014) cognitive, non-cognitive and technical skills that are acquired at secondary education are necessary in the labour market.

Table 4.1: Demographic Characteristic of the Respondents

\begin{tabular}{|l|l|l|l|}
\hline Variables & & Frequency & Percentages \\
\hline Gender & Male & 86 & 63.2 \\
\hline & Female & 50 & 36.8 \\
\hline Age & Total & $\mathbf{1 3 6}$ & $\mathbf{1 0 0}$ \\
\hline & $18-25$ & 59 & 43.4 \\
\hline & $26-35$ & 77 & 56.6 \\
\hline Marital Status & Total & $\mathbf{1 3 6}$ & $\mathbf{1 0 0}$ \\
\hline & Married & 58 & 42.6 \\
\hline & Single & 72 & 52.9 \\
\hline & Separated & 6 & 4.4 \\
\hline Level of Education & Total & $\mathbf{1 3 6}$ & $\mathbf{1 0 0}$ \\
\hline & Primary & 19 & 14.0 \\
\hline & Secondary & 56 & 41.2 \\
\hline & College/Polytechnics & 42 & 30.9 \\
\hline & University & 19 & 14.0 \\
\hline & Total & $\mathbf{1 3 6}$ & $\mathbf{1 0 0}$ \\
\hline
\end{tabular}

\section{Source: Research Data, 2018}

\section{Courses Undertaken by the Respondents}

Table 4.2 below illustrates the courses that had been pursued by the youth group members. The findings revealed that most of the youths $(29.4 \%)$ participating in groups had not undertaken any post-secondary course to advance their skills, although it was also found that some youths had undertaken some various courses such as business related, science related and vocational training. 
Table 4.2 Courses Undertaken by youth self-help group members

\begin{tabular}{|l|l|r|r|}
\hline \multicolumn{2}{|l|}{ Courses } & Frequency & \multicolumn{1}{|c|}{ Percent } \\
\hline \multirow{4}{*}{ Business Related } & 18 & 13.2 \\
\cline { 2 - 4 } & Science Related & 17 & 12.5 \\
\cline { 2 - 4 } & Vocational & 33 & 24.3 \\
Training & None & 40 & 29.4 \\
\cline { 2 - 4 } & Others & 28 & 20.6 \\
\cline { 2 - 4 } & TOTAL & 136 & 100.0 \\
\hline
\end{tabular}

The high number of youths without advanced skills from the post secondary education is an indication that most of the youths enter the labour market without any specialized skills and this impact negatively on the performance. According to (Kaane, 2014) in Kenya, over one million youths enter the labour market without any skills because of school dropout or failure of the youths to enrol to any college/polytechnics. An interview with the youth group officer in Aldai constituency indicated that most youths underrate enrolling to local polytechnics, this may have contributed to high number of youths without advanced skills.

\section{Skills offered at group training to the respondents}

Training at the group level was found to be one of the ways youth acquired skills in their groups. The study revealed that $37.7 \%$ of the respondents had been trained on entrepreneurship skills, $30.9 \%$ were trained on vocational and technical skills, management, environmental and marketing skills were $12.5 \%, 3.7 \%, 2.9 \%$ respectively. Some of the respondents $(12.5 \%)$ believed they had not acquired any skills on training. An interview with Aldai Uwezo fund youth group trainer indicated that they had been collaborating with specialist to train youth groups on various skills such as poultry farming by Chepturer youth group.

Table 4.3: Skills Acquired on Training

\begin{tabular}{|l|l|r|r|}
\hline \multicolumn{2}{||}{ Skills } & Frequency & \multicolumn{1}{c|}{ Percent } \\
\hline \multirow{7}{*}{$\begin{array}{l}\text { Entrepreneurship Skills } \\
\text { Vocational and Technical }\end{array}$} & 51 & 37.5 \\
\cline { 2 - 4 } & Skills & 42 & 30.9 \\
\cline { 2 - 4 } & Management Skills & 17 & 12.5 \\
\cline { 2 - 4 } & Environmental Conservation & 5 & 3.7 \\
\cline { 2 - 4 } & Marketing Skills & 4 & 2.9 \\
\cline { 2 - 4 } & None & 17 & 12.5 \\
\cline { 2 - 4 } & TOTAL & $\mathbf{1 3 6}$ & $\mathbf{1 0 0 . 0}$ \\
\hline
\end{tabular}

Training of the youth groups at the group level is more convenient as it has been identified in the study where majority of the youths believed to have acquired entrepreneurship skills. The study by (Moraa, Bor, \& Mwangi, 2014) also indicated that $97 \%$ of the youth group members believed on skill development at the group level. The two studies support (Akpomuvie, 2010) sentiments on the extension approach where rural people are trained on modern agricultural skills to improve on their livelihoods.

\section{Income Generation in the Youth Self Help Groups and Adequacy to the Members}

The respondents were asked whether the income they earned from the group was adequate to meet their needs and whether they had made any investment from it. Table 4.4 below illustrate frequency distribution on the feedback about the income adequacy of the respondents.

Table 4.4: Adequacy of the Income on Needs

\begin{tabular}{|l|r|r|}
\hline \multicolumn{1}{|c|}{ Income adequacy } & Frequency & \multicolumn{2}{c|}{ Percent } \\
\hline Very Adequate & 10 & 7.4 \\
\hline Adequate & 54 & 39.7 \\
\hline Not Adequate & 72 & 52.9 \\
\hline TOTAL & $\mathbf{1 3 6}$ & $\mathbf{1 0 0 . 0}$ \\
\hline
\end{tabular}


From the findings above, majority of the respondents (52.9\%) acknowledged that the income from the youth group projects was not adequate to meet their daily needs. On the other hand, a few numbers of the respondents $(7.4 \%)$ were satisfied with the income. The findings above therefore are negative indication of skill utilization in the informal sector. The study had found that most of the respondents had secondary education and they had undertaken other various training at the group level but the outcome were found to be inadequate to sustain youth livelihoods.

The table below is a cross tabulation of the courses that were undertaken by the respondents and the investments they had made from the youth group income.

TABLE 4.5: A Cross tabulation of Courses Undertaken and the youth Investment

\begin{tabular}{|c|c|c|c|c|}
\hline \multirow{2}{*}{\multicolumn{2}{|c|}{$\begin{array}{ll} & \text { COURSES } \\
\text { UNDERTAKEN } & \end{array}$}} & \multicolumn{2}{|c|}{ INDIVIDUAL } & \multirow[t]{2}{*}{ Total } \\
\hline & & Invested & not invested & \\
\hline \multirow{2}{*}{$\begin{array}{l}\text { BUSINESS } \\
\text { RELATED }\end{array}$} & Count & 11 & 7 & 18 \\
\hline & $\begin{array}{l}\% \text { within Individual } \\
\text { Investment }\end{array}$ & $12.4 \%$ & $14.9 \%$ & $13.2 \%$ \\
\hline \multirow{2}{*}{$\begin{array}{l}\text { SCIENCE } \\
\text { RELATED }\end{array}$} & Count & 13 & 4 & 17 \\
\hline & $\begin{array}{l}\% \text { within Individual } \\
\text { Investment }\end{array}$ & $14.6 \%$ & $8.5 \%$ & $12.5 \%$ \\
\hline \multirow{2}{*}{$\begin{array}{l}\text { VOCATIONAL } \\
\text { TRAINING }\end{array}$} & Count & 22 & 11 & 33 \\
\hline & $\begin{array}{l}\% \text { within Individual } \\
\text { Investment }\end{array}$ & $24.7 \%$ & $23.4 \%$ & $24.3 \%$ \\
\hline \multirow{2}{*}{$\begin{array}{l}\text { NO COURSE } \\
\text { UNDERTAKEN }\end{array}$} & Count & 28 & 12 & 40 \\
\hline & $\begin{array}{l}\% \text { within Individual } \\
\text { Investment }\end{array}$ & $31.5 \%$ & $25.5 \%$ & $29.4 \%$ \\
\hline \multirow{2}{*}{$\begin{array}{l}\text { OTHER COURSES } \\
\text { e.g ECD }\end{array}$} & Count & 15 & 13 & 28 \\
\hline & $\begin{array}{l}\% \text { within Individual } \\
\text { Investment }\end{array}$ & $16.9 \%$ & $27.7 \%$ & $20.6 \%$ \\
\hline \multirow[t]{2}{*}{ TOTAL } & Count & 89 & 47 & 136 \\
\hline & $\begin{array}{l}\text { \% within Individual } \\
\text { Investment }\end{array}$ & $100.0 \%$ & $100.0 \%$ & $100.0 \%$ \\
\hline
\end{tabular}

The study findings above indicate a negative relationship between the skills possessed by the youths and the investments they have made. It was found that respondents who had not undertaken any course were most likely $(31.5 \%)$ to invest the income they earned while those that were least likely $(27.7 \%)$ to invest were the respondents who had undertaken other courses such as early childhood education. From the findings in the study, there was no clear relationship between the courses undertaken by the youths and the investments they could make. This indicates that most of the skills acquired by the youth do not have a positive influence on their creativity in making more funds for their livelihood.

On probing further on the income generated by youth self-help groups, the study found out the comparison between education level and the income earned by the group members. Table 4.6 below is a t-test indicating the relationship between education level and the income earned by the youth group members. 
Table 4.6: A Comparison of Income of the Youth Group Members with their Level of Education

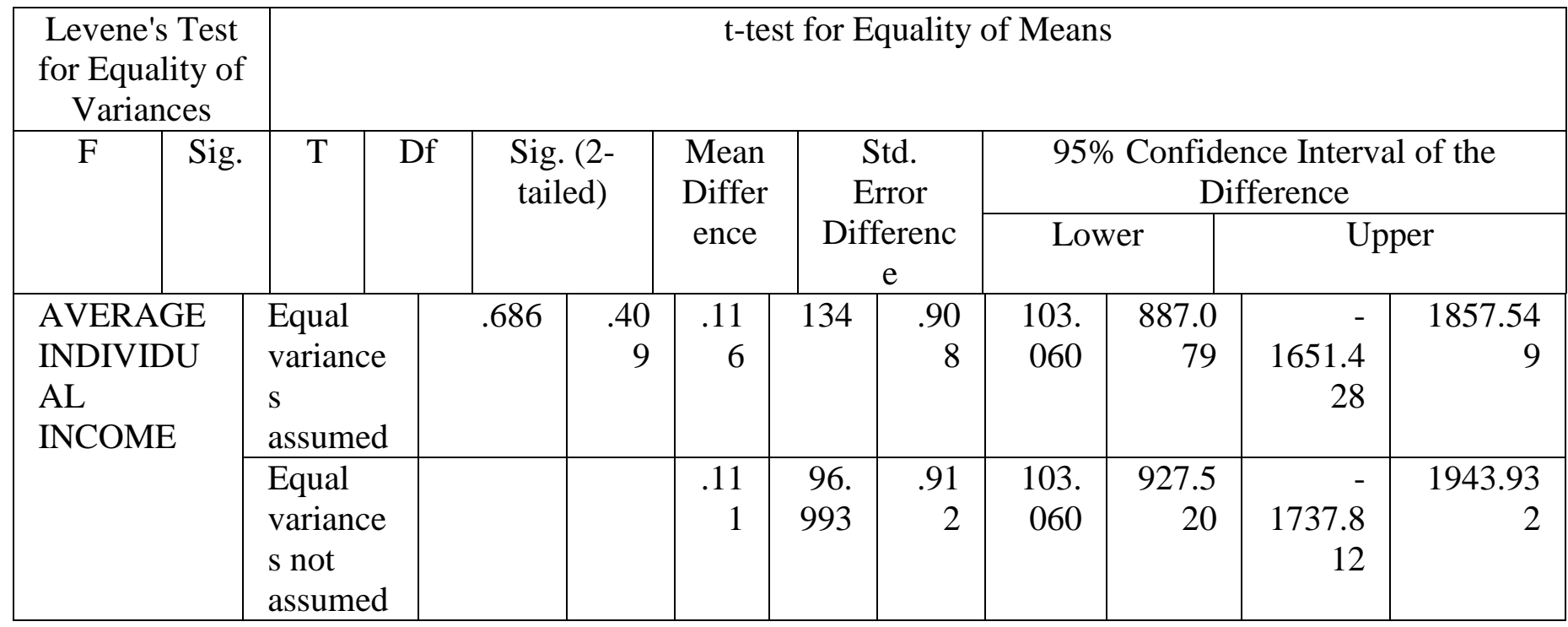

An independent-sample t-test was done to compare the the average income of the youth group members with their level of education. There was no significant difference between the income for those youths with basics education $(M=6586.67, S D=3976.60)$ and those with higher education $(M=6483.61, S D=6294.16 ; t=0.12$, $\mathrm{p}=0.91$, two-tailed). The study findings could be an indication of youths participation in non skill activities for income generation. Specialization in the group activities could also be minimal and this might be the reason why there was no difference on income between youths with advanced skills and those with basic.

\subsection{Conclusion and Discussion}

The Performance of youth self-help groups in the study has been found to be low. The government of Kenya has been encouraging youths to form youth groups in order to access finances from the government to improve on their livelihoods but the philosophy has not influenced much on livelihood sustainability. According to (Davos-Klosters, 2014) skill development levels should offer skills that match the labour market. Although it was found that most of the youth group members had attained the minimum level of education, the output was not equivalent with their skill levels.

The report by (ILO, 2012) indicates that the informal sector remains the major source of employment for the youths. The skills acquired by the youth groups from the academic institutions should positively influence the productivity in the informal sector and henceforth improve youth livelihoods in rural areas but this is not the case according to the study findings. The increasing population of youths has made the government to rethink on reforming and expanding youth polytechnics (Balwanaz, 2012). Entrepreneurial skills that help to enhance growth of youth projects include innovation, creativity, risk taking and business idea identification (Ibuathu \& Kubaison, 2013). The quality of skills provided at the academic institutions must meet the labour market needs and therefore it should enable youths to be self-reliant at all skill development levels.

Youth ignorance to utilize the acquired skills may also influence the performance of the youth self-help groups. Although limited funding to implement on group projects was found to be a challenge affecting most of the youth groups. According to (Ibuathu \& Kubaison, 2013), poor managerial skills affect the venturing of youths into competitive fields. Additionally, lack of accountability of youth self help group members affect negatively the outcome of the group.

\section{Recommendations}

Quality skill development is important at all levels of skill acquisition. Technical and vocational trainings are important in skill development. The government therefore needs to increase funding to such institutions to widen on the research of the job market in order to provide skills that match the labour market needs. Collaboration between the government and other non-profit institutions such as NGOs and financial institutions is necessary to offer finances and training to youths at the grassroot level. Local administration 
and leaders should also be involved in the implementation of youth programmes to help in monitoring the progress of such projects at the community level. Goodwill between the national and county government will help youth groups access funds and other resources easily.

\section{References}

[1] Africa Union. (2011). African Youth Decade 2009-2018 Plan of Action. Accelerating Youth Empowerment for Sustainable Development -Road Map towards the Implementation of the African Youth Charter. Addis Ababa, Ethiopia.

[2] Africa Union. (2006) Africa Youth Charter. Bangui, Gambia. Retrieved from http://www.un.org/en/africa/osaa/pdf/au/african_youth_charter_2006.pdf

[3] Akpomuvie, O.B. (2010).Self-Help as a Strategy for Rural Development in Nigeria: A BottomUp Approach. Journal of alternative perspective in social sciences,2(1),88-111

[4] Balwanz, D. (2012). Youth Skills Development, Informal Employment and the Enabling Environment in Kenya: Trends and Tensions. Journal of International Cooperation in Education, 15(2),69-91

[5] Brody,C., Dworkin,S., Dunbar,M., Murthy,P., \& Pascoe,L.(2013). The Effect of Economic Self Help Group Programmes on Women's Empowerment: A Systematic Review Protocol. Oslo, Norway: The Campbell Collaboration.

[6] Davos-Klosters. (2014). Matching Skills and Labour Market Needs: Building Social Partnerships for Better Skills and Better Jobs. Global Agenda Council on Employment,

[7] (January),28.Retrieved:http://www3.weforum.org/docs/GAC/2014/WEF_GAC_Employment_M atchingSkillsLabourMarket_Report_2014.pdf

[8] Diebolt, C., \& Haupert, M. (Eds.). (2016). Handbook of Cliometrics. Springer Reference.

[9] Fernandez, A. (2007). History and spread of the self-help affinity group movement in India. International Fund for Agricultural Development (IFAD

[10] Friendrich-Ebert-Stiftung foundation and institute of economic affairs, (2011). Youth

[11] Employment in Kenya -Prospects and Policies Programme: ministerial conference report, Nairobi Kenya.(sarova panafric hotel November 2011)

[12] GOK .(2015). Kenya Gazette Supplement Senate Bill.Self Help Association Bill. Nairobi: Government Printers.

[13] Ibuathu, C. N. \& Kubaison, S. T. (2013). Realizing equal opportunities amon youth groups in accessing government financial credit facilities. International Journal of Social Sciences and Entrepreneurship, 1 (7), 699-712.

[14] ILO. (2012).Youth Employment Interventions in Africa: A Mapping Report of the Employment and Labour Sub-Cluster of the Regional Coordination Mechanism (RCM)for Africa / International Labour Organization-Regional Office for Africa. Addis Ababa, Ethiopia. Retrieved from: http://www.ilo.org/wcmsp5/groups/public/--africa/documents/publication/wcms_206325.pdf

[15] Kaane, H. (2014). Policies, Mechanisms and Schemes for Integration of Youth into the Workforce and Job Creation. Kenya Country Report for the 2014 Ministerial Conference on Youth employment. Abidjan Cote D 'Ivoire.Kenya Population and Housing Census, (19892009). Kenya National Bureau of Statistics: Government Printers.

[16] King, K. (2012). Eight Proposals for a Strengthened Focus on Technical and Vocationa Education and Training (TVET) in the Education for All (EFA) Agenda. Background paper prepared for the EFA Global Monitoring report.

[17] Moraa,M.O., Bor,E.K., \& Mwangi,W.S (2014).The Role of Youth Self-Help Groups in Skill Development in Njoro. Journal of Emerging Trends in Educational Research and Policy Studies (JETERAPS) 5(5): 621-628.

[18] Mugenda, O. M., \& Mugenda, A. G. (2003). Research methods: Quantitative and qualitative approaches: Press, Acts Nairobi. 
[19] Rolleston, C. (2014). Learning profiles and the 'skills gap'in four developing countries: a comparative analysis of schooling and skills development. Oxford Review of Education, 40(1), 132-150.

[20] United Nation. (2015).United Nations Department of Economic and Social Affairs Population Division. Population Facts:Youth Population Trends and Sustainable Development: Retrieved from www.unpopulation.org 